\title{
看護における薬理学教育・研究と 人材育成の現況と課題
}

要約 : 医療のめざましい進歩, 高齢化社会の到来に伴 い, 看護師に求められる知識や技術は格段に高まって いる. このような社会の要望に応えるべく, 看護系大 学の新設が進み，間もなく 260 校に達する勢いである. 科学的根拠に基づいた実践能力, 問題解決能力育成を 目指して 4 年制教育にしたはずが，看護師不足もあり， 看護系大学の教育環境は, 臨床実践重視の傾向が顕著 になっている。 その結果, 実習時間が増え, 薬理学は じめ基礎科学教育環境は専門学校時代とほとんどかわ らないか, むしろ減っている. 数年に一度必ずといっ てよいほど, 高濃度の塩化カリウムの静脈注射やイン スリンの筋肉内注射など看護師による医療事故が起こ り, 教育機関や医療機関で努力はされていると思われ るが, 現実, これらの医療事故は, 看護師の基礎科学 教育の知識の欠如といっても過言ではない。このよう に, 看護師による薬物関連事故が後を絶たないことを 憂いながらも, 薬理学を選択制にしている大学さえあ る. 薬物治療に強い看護師育成のためには, 正常な機 能を営む生体のメカニズム, 疾病の成り立ち, 薬のも つ多様な作用とその機序の理解を徹底的に学習させる とともに，関連情報を繋げられるような教育が必要で ある. 多くの看護系大学の薬理学講義のコマ数は 15 〜16 コマで, この時間では薬の主作用, 副作用を教え るのが精一杯であろう。講義時間を増やすことが緊急 の課題である. 医療の基盤をなす基礎科学系教育の充 実こそが薬物治療, 実践に強い看護師育成につながる のだから。看護教育が 4 年制にシフトし 20 年以上経 ち, 看護系大学が増加し続ける今でも薬理学教育を医 学部や薬学部等, 他学部に依頼しているのが現状であ る. 他学部出身者と同等かそれ以上の能力を持つこと が前提であるが, そろそろ看護出身者の中から薬理学
教育・研究を担当できる人材を育て, 育ちつつある人 材を受け入れる看護基礎科学教員のポジションの確保 (専任の基礎科学担当教員を配置している看護系大学 は極めて少ない), 取り組みが看護に求められる課題 でもある。

\section{1. はじめに}

医療の目覚ましい進歩, 食生活の欧米化による疾病 構造の変化, 社会経済情勢の急激な変化, 超高齢化社 会の到来に伴い, 高度医療技術の習得, 在宅医療支援 など, 看護師に求められる知識や理解力, 技術は格段 に高まっている.

このような社会の要請に応えるべく, 高度な医療に 対応できる看護師育成をめざし, 看護系大学新設が進 められ, 2016 年 8 月現在 254 校（国立 42 校, 公立 45 校，私立 167 校）となり，その後も新設が続き，間も なく 260 校を超える見通しである.

看護系大学の入学者は, 文系選択の高校生が入学し, 薬理学をはじめとする自然科学の基礎知識を習得する にも四苦八苦の状態で, 点滴の計算もできない学生も いると聞く. 臨床では, 新人看護師の臨床実践力の低 下, 看護師不足もあり, 看護における教育研究環境は 臨床実践重視の傾向が顕著になっている。 その結果, 病院実習など実践教育に重点がおかれ, 実践能力の基 盤となる基礎科学教育環境は, 専門学校時代と変わら ない大学が多い. 科学的根拠に基づいた実践能力, 問 題解決能力, 創造力などの育成を目指して 4 年制大学 にしたはずではないのか. 看護師による薬物関連事故 は依然として後を絶たない. 何故か.

本稿では, 看護基礎科学系カリキュラムの変遷, 看 護系大学に拈ける薬理学教育の現況, 山形大学で筆者

キーワード : 看護薬理学教育 - 研究, 人材育成, 薬物関連事故, 薬理学講義時間数, 看護基礎科学教育 山形大学（テ990-2321 山形市桜田西二丁目 9-8）

E-mail: ykatano@med.id.yamagata-u.ac.jp＼cjkstart原稿受領日：2016 年 9 月 30 日，依頼原稿

Title: The current status and issues of pharmacology education and the human resource development in nursing Author: Yumi Katano 
らが取り組んだ薬物治療に強い看護師を育てる試み, 看護師による薬物関連事故がなくならない背景, 看護 における薬理学教育・研究と人材育成とその課題につ いて述べてみたい.

\section{2. 看護教育における基礎科学系カリキュラム の変遷}

看護教育の内容は，国が定めた指定規則に基づいた カリキュラムによっておこなわれている，統一された カリキュラムが登場したのは, 1950 年（実施は翌年の 1951 年), それまでは各学校独自のカリキュラムで養 成が行われていた (1)。その後, 看護教育課程おける 指定規則は，年々高度化する医療に対応できる看護師 養成を目標に，たびたび改正が行われている，基礎科 学系科目に焦点をあてると（表 1), 解剖生理学は, 1950 年に 90 時間と指定されたのが, 1967 年には解剖 学と生理学に分けられ (それぞれ 45 時間), 1989 年に は再び解剖生理学 120 時間に変更された。薬理学は 1950 年と 1967 年に 30 時間だったのが, 1989 年には 45 時間に増えている.

1996 年になると, 看護教育を従来の専門学校中心か ら 4 年制の大学教育への移行が図られた。この年から カリキュラムの充実・弾力化を目的に単位制が導入さ れた。基礎科学系科目は,「人体の構造と機能」と疾病 の成り立ちと回復の促進」の 2 大項目にまとめられ, 両方あわせて 15 単位に改正された。各科目に配分す る単位 (時間) 数や科目の名称は, 各教育機関の裁量 に任されることになった．現在の看護基礎医学系教育 は，この 1996 年改正カリキュラムに基づいて実施さ れている.

看護基礎科学系科目の講義時間数は, 4 年制教育に 移行した現在でもほとんど変わっていないことがわか る. むしろ単位制が導入され, 各科目に配分する単位 (時間) 数や科目の名称は各養成機関の裁量に任され ることになった結果, 薬理学という授業科目が選択制 になっている大学やカリキュラムに薬理学という名称
が見あたらないところもある．薬に関する内容が疾病 論等に含まれているのだろうか.

看護教育に携わった経験がある教員は，筆者同様， 看護学生の傾向として，真面目によく努力し，暗記科 目は得意であるが，論理的思考過程をたどることが苦 手, 創造力, 自己学習力に乏しい, また関連のある複 数情報を繋げることが苦手な学生が多いことを指摘し ている。 それに対して, 文部科学省では, 問題解決能 力，創造力などの育成を課題としてあげている。 その ことを指摘しながらも, 知識や理論中心の教育から, 現場に出てすぐに対応できる看護実践能力育成を目指 し(1)，4 年制の看護教育においても，臨床実践重視の 傾向が顕著になっている.

看護師の質がいいかどうかは，医療保健の質を左右 する。この看護職の質の良否は継続教育も大事である が，最初に受ける教養科目をはじめとする基礎教育が 大変重要である $(2)$.

大学教育で多角的に物事を捉え, 分析する力を養い, 看護学のみならず関係諸科学を駆使して実践を分析し ていく力の基盤を築き，実践で切碰环磨していくこと が求められている。 この基盤となる学問こそ基礎科学 教育であろう。基礎科学教育を理解するには, 多少と も生物学, 化学, 物理学の知識, 考え方が大切となる. 文系志望の学生が看護系大学に入学するので “さもあ りなん”の状況である。 このような状況下で, 指定規 則の変遷からみえるのは, 看護基礎科学系科目の講義 時間数は， 4 年制教育に移行した現在でもほとんど変 わっていない，これは目指す大学教育と矛盾しないだ ろうか.

\section{3. 看護系大学における薬理学教育の現況}

“患者には必ずといってよいほど，薬物治療が行わ れている”といっても過言ではない。薬は疾病の治療 に欠かすことのできない物質であるが，用い方によっ てはむしろ健康を害す。“クスリはリスク”にもなる 諸刃の剣の関係にある。 それは何故か. クスリは多様

表 1 看護教育課程における基礎科学系科目の変遷

\begin{tabular}{|c|c|c|c|}
\hline 1950 年（昭和 25 年） & 1967 年（昭和 42 年） & 1989 年（平成元年） & 1996 年（平成 8 年） \\
\hline 解剖生理学 : 90 & $\begin{array}{l}\text { 解剖学 : } 45 \\
\text { 生理学 : } 45\end{array}$ & 解剖生理学 : 120 & \multirow{4}{*}{$\begin{array}{l}\text { 「人体の構造と機能」と } \\
\text { 「疾病の成り立ちと回復 } \\
\text { の促進」あわせて } 15 \text { 単位 }\end{array}$} \\
\hline 栄養学 : 45 & 生化学（栄養学含む）：45 & $\begin{array}{l}\text { 生化学 : } 30 \\
\text { 栄養学 : } 30\end{array}$ & \\
\hline 薬理学 : 30 & 薬理学 (薬剂学含む) : 30 & 薬理学 : 45 & \\
\hline 細菌学：45 & $\begin{array}{l}\text { 微生物学 : } 45 \\
\text { 病理学 : } 45\end{array}$ & $\begin{array}{l}\text { 微生物学 : } 45 \\
\text { 病理学 : } 75\end{array}$ & \\
\hline
\end{tabular}

表記年は改正年度, 実施は翌年から. 各科目の数字は授業時間数. 
な作用をもっていて，副作用のない薬はほとんどない からである，ヒトにとって，薬物の作用を良い・悪い だけで決めているだけで, 薬物には罪がない, 薬理作 用や使い方の知識が重要となる。薬理学を学ぶ目的は, 薬物を正しく用いることにより, 副作用をもたらすこ となく疾病の回復を促進することにある。薬の正しい 使い方, 薬物相互作用の理解には, クスリの多様な作 用とそれらの機序を知ることが不可欠である. 薬理学 は, 解剖学, 生理学, 病態生理学, 生化学, 微生物学 等幅広い関連領域の理解が必要な学問である。ところ が, 看護におけるこれらの講義時間は極めて少ない (表 1).

看護系大学の“薬物治療に強い看護師教育” 実施状 況を知るために, 薬理学 (臨床薬理学) 開講状況と授 業時間を調べた。

シラバスを公開していない大学が多く, 調べられる 範囲ではあるが, 薬理学実施状況を表 2 に示す。講義 時間数にばらつきがあり, しかも講義は選択制のとこ ろ, 薬理学関連授業名がないところも見られた（薬理 の内容が, 病態学や疾病論などに含まれている可能性 は否定できない).

看護系大学の講義時間数がこのように違うのは, 前 項でも述べたが,「人体の構造と機能」と「疾病の成り 立ちと回復の促進」の 2 大項目に，それぞれ割り振ら れた総時間数をどのように配分するかは各教育機関に ゆだねられているためであろう。

薬理学 (臨床薬理学) 教育は, 医学, 薬学部, 薬剤 部などからの学内講師, 外部非常勤によるオムニバス 形式によって行われているところが大半で, 専任教員 を置いている看護系大学はわずかであった.

\section{4. 看護師による薬物関連事故と教育のあり方}

看護教育が 4 年制教育にシフトしている現在でも, 薬剂の間違い, 薬の量, 与薬ミス (与薬ルート, 与薬 速度, 与薬時間) 等, 看護師が関与する薬物関連事故 は後をたたない，看護師による薬物関連事故のニュー スを耳にする度に，いずれも薬を知らなすぎることが 第一の原因ではないかと, 教える立場にいる者として 心を痛めている．多くの看護系大学の薬理学講義時間 は， 4 年間で 15〜16コマ（1コマ90 分換算）である (表 2). この時間内では, 主要な薬物の名称とそれら の主作用，副作用を教えるのが精一杯であろう。この ような講義を受けた学生は, 難解でもっとも苦手な教 科に薬理学をあげている。目の前の試験に合格するた めに丸暗記し, 結局薬の持つ多様性や機序の理解や知 識が全くないままに臨床にでてしまうのが現状であり，
表 2 看護系大学における薬理学授業コマ数

\begin{tabular}{|c|l|}
\hline $\begin{array}{c}\text { 薬理学 } \\
\text { (臨床薬理学) }\end{array}$ & \multicolumn{1}{|c|}{ 大学名 } \\
\hline 30 コマ & 山形大学, 山形県立保健医療大学 \\
\hline $23 \sim 24 コ マ$ & 東海大学 \\
\hline 20 コマ & 大分県立看護科学大学 \\
\hline $15 \sim 16 コ マ$ & $\begin{array}{l}\text { 北海道大学, 弘前大学, 東北大学, 千葉大学, 東 } \\
\text { 京医科歯科大学, 横浜市立大学, 神戸大学, 大阪 } \\
\text { 市立大学, 島根大学, 九州大学, 順天堂大学, 聖 } \\
\text { 路加国際大学, 杏林大学, 帝京大学, 自治医科大 } \\
\text { 学, 川崎医療福祉大学, 大阪医科大学, 宮崎大学 }\end{array}$ \\
\hline 8 コマ & 大分大学, 北里大学, 日本赤十字看護大学 \\
\hline $\begin{array}{c}\text { 授業コマ数 } \\
\text { 不明 }\end{array}$ & 上智大学, (1 単位), 名古屋大学 (1 単位) \\
\hline
\end{tabular}

講義時間数：90 分授業を 1 コマ換算したもの.

看護系大学数 (2016 年 8 月時点) : 254 校 (国立 42 , 公立 45 , 私立 167)（回答をいただいた大学とシラバス公開大学からのデータ).

これが薬物関連事故がなくならない主な原因ではなか ろうか.

年々増加する看護師による薬物医療事故 (3) は, 薬 物の相互作用に関する事故も少なくない $(4,5)$ 。これ は, 看護師の臨床薬理学的知識の不足が要因のひとつ であると指摘している(6).

事故防止対策のひとつに, 看護継続教育として臨床 薬理学教育を行うことを提案している(7). 実際, 大 学病院や地方病院で薬剤事故防止を目的に, 薬郕に関 する教育を行っているが, 全体の継続教育時間に対し て占める割合は約 10\%程度と少ないという (7).

筆者が修士学生を対象にした薬理学教育では, 疾病 と関連づけながら薬の持つ多様性や作用機序の説明に 時間を割いていた。そこには元病院看護部長や臨床経 験の長い看護師が多く参加しており,「機序などわか らずに使っていたけれど，無知で恐ろしいことをして いたのですね.こういう教育を受けたかった」と目を 輝かせて学ぶ姿をみるにつけ, 薬の多様性や機序を学 ばずに臨床にでた看護師には, 薬に関する継続教育が 必要であることを痛感した，確かに継続教育も大事で あるが，まずは学部における薬理学 (臨床薬理学) 教 育の充実, そのためには授業時間の確保と授業の工夫 が重要ではないだろうか.

残念ながら, 看護教育界からそのような提案はでて こない.むしろ「従来の科学教育では, 看護は本来 人々の健康と福祉を実現することを目的としながら, 実際は“人を器官や臓器の集合体としてとらえる”と いうような科学的人間像をつくりだしてしまった」 （8）という批判すらある。このような科学的人間像を 作り出すことを恐れ, 基礎科学教育, 薬理学教育を増 やすことをよしとしないのだろうか. 医療系基礎科学 
教育に携わる教員が，上記のような考えで教育に携 わっているであろうか，否である，最終目標は，健康 を目指し，その科学的根拠を考えるために教育を行っ ているはずである。このように，基礎科学教育に対し， 看護職者と基礎科学教育に携わる者との間に乘離があ ると感じるのは筆者だけであろうか. この乘離を埋め るには, 基礎科学科目担当者と看護専門担当者の相互 理解と協働が必要であろう。

看護師国家試験の問題も関係している. 看護系大学 の設立が 260 校にも及んでも, 看護師国家試験難易度 は, 看護専門学校時代の内容であり, 改善されていな い. 看護師国家試験内容を再考し, 基礎科学知識を加 えることが必要な時期である。医師が求める看護師 像と看護師が求める看護師像をもう一度再考し, 看護 師国家試験内容を吟味しなければならない時期が来て いる.

\section{5. 看護における薬理学教育の重要性と授業の 工夫}

山形大学医学部看護学科は, 1993 年, 東北北海道地区 初，全国では 21 番目の 4 年制看護学科として発足した.

山形大学では看護学科設置以来, 小手先の暗記に頼 らない科学的思考力・観察力・表現力を伸ばすことが, 実践能力をもつ医療者, また教育・研究者の育成につ ながるという信念のもと, 基礎科学系に専任教員を配 置するなど基礎科学教育にも力を入れている.

筆者が看護学科に就任したのは 1995 年だが，兼任 (医学部薬理学講座) 教員として, 1 期生（1993 年入 学) 加人体機能学, 病態生理学, 薬理学, 卒業研究 を担当した，薬物治療に強い看護師育成を目指し，筆 者 (2009 年退職) と後任の故石幡明教授とで看護学科 在任中に試みた教育・研究, 人材育成の一端を紹介さ せていただく

医療の進歩はめざましく, 今や分子や細胞の理解な くして薬理学 (臨床薬理学) 講義をすすめることがで きなくなっている. 山形大学医学部看護学科の薬理学 講義時間は 30 コマ（1コマ90 分換算, カリキュラム 上の授業時間は 2 単位, 60 時間）で他校に比べ多い方 であるが，それでも主要な薬物について使用法から多 様な作用とそれらの機序等の理解には, 生理学, 病態 機能の復習が必要で, 30 コマでは十分な時間とは言い 難い，幸い筆者は人体機能学, 病態機能学, 薬理学の 3 教科を担当することになったので，正常な機能を営 むためのメカニズム等 (生理学), 正常な機能が破綻を きたすメカニズムと病状等 (病態生理学), その疾病 (病気) の回復を促進する薬について, 多様な作用とそ
の機序，正しい使い方等を，3 教科を組み合わせるこ とで，それぞれの講義時間は短いながら比較的流れを つくって説明でき，いくつか実習を組むこともできた. 実習の一例として血圧実習について紹介する。各班 (6, 7 名) 毎に提案させた $3 \sim 4$ テーマについて血圧変 動を記録, 考察, レポート提出, 後日学生による発表 会を行った. 看護学生らしく, 運動, 飲食, 食べ物の 種類, 温度変化, 足浴, アロマ効果, 恐怖等様々なテー マを取り上げ，それらと血圧変化について，喜々とし て取り組んでいた，その中の一つに「カリウムを含む 食品摂取は血圧を本当に下げるか，これを検証してみ たい」があった。カリウムを含む食品としてよく知ら れるバナナを食べたが血圧が変化しないという，何か 間違ったことをしていますかと質問してきた。ここが 面白いところで, 優秀な学生であったが, 健康番組でも よくとりあげられる「カリウム = 血圧を下げる……」 そのことで頭が一杯なのか, 摂取量や投与経路によっ て効果の出方が違うことまで考えが及んでいないこと に, 講義の難しさを実感した. しかし人体機能学, 総 論や各論ですでに学んでいるので少しヒントを与える ことで，学生達はすぐ納得してくれた，学んでいない まま臨床にでていたらどうなるか，看護師による痛ま しい塩化カリウム死亡事故を想いぞっとした.

\section{6. 看護における薬理学教育・研究と人材育成 一卒業研究 (看護研究) は, 薬理学教育 - 研究 と人材育成の第一歩!}

看護教育において研究的態度を身につけることの重 要性が説かれるようになり，1989 年（平成元年）のカ リキュラム改正に伴い，看護教育の中に看護研究の科 目を設け，卒業研究が取り入れられるようになった (9). ところが, 看護系大学のうち国公立のほとんど は卒業研究を必修にしているが, 看護系大学の約 70\% を占める私立大学 (2016 年 8 月現在) の多くは必修と はしていない，方法論や研究の概要を学ぶにとどまり， 卒業論文を作成することなく卒業している $(10)$.

卒業研究 (看護研究) は, やり方次第ではあるが, 講 義, 実習中心の受け身的教育からの脱却であり, 創意 工夫, 計画性, 洞察力, 論理的思考能力, 問題解決能 力, 表現力が培われ, これは現場に出てから自分の頭 で考え, 解決, 未知の場面に対処できる能力を育成す るまたとない教科ではなからうか.

山形大学医学部看護学科の卒業研究 (学科設置以来 必修科目）では, 看護専門講座は主に質的・量的研究 等 (一部実験研究も取り入れている), 基礎科学系（解 剖学, 生理薬理学, 微生物学) に所属する 3 教員は開 
設時以来実験研究を実施している．筆者らは，科学的 根拠に基づいた生活習慣病の予防，改善，指導に当た れるような課題および老化に関する実験研究を実施し ていた。

本学科の卒業研究のタイムスケジュールは, 現在, 卒研生の配属決定を 3 年次の $1 \sim 2$ 月, 11 月中旬卒研 発表会, 12 月卒業論文提出となっている。この間も講 義や実習が組まれているため, 筆者のような実験研究 の場合, カリキュラム通り週 2 3 回では足りない. そこで配属希望者には，土日を返上してでも実験研究 をやりたいという学生のみを受け入れていた。 それで も希望者は多く, 実際土日返上で夜遅くまで頑張る学 生達の姿に元気をもらっていた，卒業研究でも思わぬ 発見があり, 成果も得られ, 国内の学会で発表, 論文 投稿もできた，成果がでてくるとさらに研究意欲が上 がるもので大学院進学に繋がった。 こうして 1996 年 から 2014 年までに片野・石幡研究室を巣立った卒業 研究生 104 名, そのうち 27 名が筆者達の大学院修士 課程 (病態機能学分野) に進学, 学位を取得した後, 現 在大学教員, 看護師・保健師, 研究者として全国各地 で活躍している，喜ばしい限りである.

なお, 全国の看護学科に生命科学系の研究と教育を 根付かせ, 看護の中から教育・研究を担当できる人材 育成の必要性を痛感し, 故石幡教授が 2011 年に「基 礎科学をもとにしたCo-Medical 研究会」を立ち上げ, 研究会雑誌を発行し, 現在に至っている.

当初, 看護に基礎医学教育はいるの? 実験研究なん て何になるの？という声が聞こえてきたのには驚いた が，何と言われようと看護教育を 4 年制教育にした以 上, 医学的な知識を備えた上で看護専門領域教育を担 当できる人材育成を目指してきた，実際，本学の看護 病態機能学系, 解剖系, 微生物学系から教育・研究を 担える人材が大勢育っている. しかし彼, 彼女らを受 け入れる基礎科学教員ポジションが看護系大学にはほ とんどないのが現状である.

薬理学を含め基礎科学教育に専任教員を配置してい る看護系大学は少なく, 看護薬理学教育を医学, 薬学 等他学部に依頼したままである．他の教育分野と同様 に, 看護教育も専門学校教育から大学教育にしたから には, 看護教育に必要とされる薬理学などの基礎科学 を専門とする研究者を養成し, 医学・歯学・薬学など 医療分野における自然科学学会で討論できる大学教育 者・研究者が, 現実として必要になっている.

医学部を作るには, 附属病院が必要, 教員数（学生の 定員により違うが）120１30人の専任教員（常勤）が必 要であるのに対し, 看護系大学 (学部) の場合は, 制度
的（大学設置基準）には 21 名の専任教員, 図書館を含む 教育施設の設置などが求められているだけである (2).

このような事情もあり薬理学はじめ基礎科学教育を 他学部に依頼しているのであろうか？ 定員削減など 教育を取り巻く環境が厳しくなっていることは承知し ているが，看護教育を 4 年制にシフトして 20 年以上 経ち, 看護系大学が 260 校にも迫る中, そろそろ看護 出身者の中から基礎科学教育を担う人材育成にも目を 向けるべきではなかろうか.もちろん他学部出身者と 同等かそれ以上の教育・研究能力が要求されることは 論をまたないが．育ちつつある人材を育てるためにも， その受け皿となる基礎科学専任教員のポジションの確 保を強く願ってやまない.

\section{7. おわりに}

\section{1）薬物治療に強い看護師を育てるためには}

・薬理学はもとより基礎科学系教科を充実させること. - 薬物作用機序の理解が重要であり, 機序の理解に よって臨床応用例や副作用の予測が可能となる。 そ のためには授業時間の確保が不可欠である.

・薬物関連事故を防ぐには, 薬理学での学びを臨床に 繋げるために看護専門科目担当教員との協働が欠か せない.

\section{2）看護における薬理学教育・研究者育成について}

看護教育が 4 年制にシフトして 20 年以上経ち, 看 護系大学が 260 校にもなろうとしている現在でも, 看 護薬理学教育を他学部に依頼したままで良いのだろう か. 看護出身者の中から薬理学教育・研究を担当でき る人材を育て, 育った人材を受け入れる基礎科学専任 教員のポジションの確保，取り組みを願ってやまない.

謝辞：本稿作成にあたり, 貴重な助言をいただいた浜松医 科大学医学部看護学科薬理学部門渡邊泰秀教授に, 資料提 供をいただいた「基礎科学をもとにしたCo-Medical 研究会」 会員の皆様に感謝の意を表します。

筆者の利益相反：開示すべき利益相反はない.

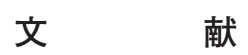

1）武分祥子. 立命館産業社会論集. 2005;41:229-241.

2) 草間朋子. 看護科学研究. 2012;10:26-36.

3) 財団法人日本医療機能評価機構医療事故防止事業部, 医療事 故情報収集等事業. 平成 24 年事業のご案内. 2012. p. 1-14.

4) 長谷川純一. 鳥取医学雑誌. 2007;35:3-9.

5) 内田信也,他. ぶんせき.2007;9:454-460

6) Page K, et al. Today. 2007;27:219-224.

7) 松田明子,他. 米子医誌. 2013;64:107-113.

8) 内田雅子. 大分看護科学研究. 2001;3:21-24.

9) 中村郷子, 他. 日本看護研究学会雑誌. 2007;30:89-96

10）高梨あさき.基礎科学にもとづいたCo-Medical 研究会雑誌 2016;4:6-7. 